\title{
PEREIRA, Helder Moura. Mútuo consentimento. Lisboa: Assírio \& Alvim, 2005.
}

Edgar Pereira

Universidade Federal de Minas Gerais

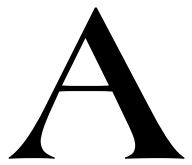

relação entre poesia e desconstrução da subjetividade é um dos parâmetros da literatura moderna, naquilo que ela possui de mais avançado. Minar a soberania do eu, destruir os pressupostos da personalidade poética (fidelidade, sinceridade, coerência), jogar suspeição sobre o espaço subjetivo, tudo isso no âmbito literário provém da idéia rimbaudiana de que o eu é um outro. Sem abolir o seu caráter visceralmente individual, a lírica, entretanto, não tem a presunção de negar a mediação do universal: o individual é mediado pelo universal e vice-versa, segundo brilhante e conhecida argumentação de Adorno em "Lírica e sociedade". A idéia de subjetividade passa a comportar outras nuanças, algumas até pouco tempo contraditórias, tais como a abertura para a alteridade, a pluralidade e a diferença, moldandoa aparentemente no contrário daquilo que ela se sabe. A flexibilidade do pensamento (e das pulsões) à diversidade sexual, étnica e cultural é transformada em mais-valia poética, impelindo para um estágio humano de inter-relações e intercâmbios produtivos. As mutações da subjetividade na poesia contemporânea delineiam menos o interesse em decifrá-la do que reinventá-la, nem que seja para, na esteira de Blanchot, aceitá-la como o outro em mim, com a intromissão da exterioridade e a interface dos novos fluxos e conexões do contexto urbano.

A poesia mais recente de Hélder Moura Pereira, do outro lado do atlântico, segue nessa direção, em especial o poema "Em que língua gritas tu, meu pesadelo", onde se lê: "Um assobio, uma pequena linha de seiva/ e os dois com falta de paciência, leva-me,/ poesia, na escada do desacerto e faz/ de mim um lavador de pés, um menino/ moldavo a limpar vidros nos semáforos". Tomando-se a si próprio como objeto de reflexão, 
cabe ao poeta desenvolver um saber de si e do mundo; o sujeito poético de Mútuo consentimento assume uma postura niilista como forma de resistência, afirmando sem rodeios em "Alimento um do outro, conversas": "eu sou um cantor de vazio". A ênfase dada à metalinguagem, a reiterada alusão ao trabalho poético, (a nomeação obsessiva de um emblemático livro "de poesia") acaba criando um jogo especular, outorgando à literatura uma função de resistência diante da opressão dos objetos e do estreito mundo do consumo.

A subjetividade dilacerada (o dilaceramento é uma constante dos niilistas) não se constrange em tocar o limiar do poço ou mesmo vislumbrar a fatalidade do próprio naufrágio, promovendo a aliança entre a dor e o sonho, (a lírica compreendida como a voz em que dor e sonho se acasalam, no entender de Adorno): "Sem amor a gente anda por aqui/ a gemer de dor por dentro, é a verdade/ pura e simples e o resto é conversa", desabafa o poema "A morte afinal não custa nada, diz-me". Noutro poema, de que vale a pena citar a primeira estrofe, a desenvoltura como o sujeito passa do universal para o individual surpreende: "Chegado a uma árvore, dessas árvores/ rectilíneas a que tiraram folhas breves/ para fazer chá contra as enxaquecas/ e os males dos joelhos, penso (é um frouxo/ pensamento, mas é um pensamento)/ que a vida passou e, sem amor, nada é". Não menos surpreendente a fusão entre o sujeito, isento de resíduo de qualquer matéria, e a linguagem: "Nos teus braços estou quieto, canto baixo/ e adormeço. Sei que o amor, afinal, vem disto:/ não esperar de ninguém nada de nada".

O pós-moderno aceitará ironicamente que o eu é um outro, mas tem limites. Uma decorrência deste conluio diz respeito ao entrelaçamento cada vez maior do processo de elaboração poética com o lastro temático construído pelo sujeito da experiência. Dito de outro modo, a expressão poética possibilita evidenciar o diálogo entre o sujeito da enunciação e o legado de talento, engenho, assombros e perdas (a fusão adorniana de dor e sonho no âmbito da lírica) que, via de regra, caracteriza o discurso poético. Resta afirmar que o discurso crítico nesse caso invariavelmente terá que se submeter ao espaço secundário da inútil paráfrase, do eco inferior. Como discurso de segundo grau, entretanto, a fortuna crítica não deixa de fornecer substrato para a criação subseqüente. Joaquim Manuel Magalhães, referindose a Moura Pereira, afirma: "Devemos agradecer ao quotidiano e à mágoa verbalmente ordenada deste poeta que seja um dos poucos que nos lembram a necessidade de a poesia escapar aos lugares-comuns do tempo" (Os dois crepúsculos.1981, 
p.274). As glosas críticas tornam-se matéria de poesia, configurando um processo de releitura do próprio percurso textual, como se infere nos segmentos: "Com cinco letrinhas apenas/ se escreve a palavra morte e se bem que/ a palavra morte ocorra vezes sem conta/ há uma outra palavra que não deixa/ de apertar o coração. Também cinco/ letrinhas apenas e é a palavra corpo". No poema "Agora é só esvaziar a pasta dos itens", são feitas articulações entre amor/ mágoa, morte/corpo, universos sintagmáticos privilegiados na obra do Autor, signatário de um verso paradigmático - "A mágoa é um vício, a ele volto/ pelas madeiras desta casa", (De novo as sombras e as calmas, 1990,196) - agora retomado e desdobrado no poema referido: "Se calhar vais dizer que a seguir/vem a palavra mágoa e um regresso/ aos primeiros tempos. Não vem nada”.

Hélder M. Pereira é um poeta ligado desde sua estréia coletiva, em 1976 com os poemas amassados de Cartucho, junto com Joaquim Manuel Magalhães, Antonio Franco Alexandre e João Miguel F. Jorge, a uma escrita discursiva, marcada pela reabilitação da subjetividade, ambigüidade sexual, recusa da ênfase e uma linguagem límpida e rasa. Estes são nomes fundamentais da poesia portuguesa contemporânea, com uma produção diversificada e com influência em vários poetas mais novos. A opção pelo verso discursivo e por um erotismo minoritário (mais ou menos visível em cada caso), a que o contexto luso dos anos 70 acrescentou tons libertários (a recusa à fragmentação e à ocultação do sujeito praticadas pelo grupo poesia 61, o aflorar de movimentos gays), transforma Cartucho num divisor de águas, a despeito da negação dos próprios autores. O título em questão é o vigésimo sétimo de uma produção intensa e instigante de Moura Pereira, na qual se destacam Entre o deserto e a vertigem (1979), Sedução pelo inimigo (1983), Gestos de Miradoiro (1984), Para não falar (1986), Romance (1987), Carta de rumos (1989), Um raio de sol(2000) e Lágrima (2002).

O traço inventariante desta poesia aponta para um enquadramento densamente reflexivo, em que pesem as reiteradas alusões ao duplo, as referências culturais, as querelas identitárias, as questões urbanas, a ambigüidade sexual e os jogos intertextuais, elaborados com notas de ironia e comedida expansão. Somemse a este receituário o gosto em ultrapassar fronteiras, a vizinhança ostensiva do cotidiano, o distanciamento corrosivo, o desequilíbrio entre o excesso de explicações e a lucidez da escrita, como se lê em "Toda a gente sabe o número da praia": (...) "porque/ ao escrever amigo é mesmo amigo e nunca/ 
aconteceram confusões de ciúme/ entre amizade sem sexo e sexo/ sem amizade". A multiplicidade de explicações redunda inócua, tornando-se parte da própria confusão. Com a velocidade do ritmo, apta na apreensão da mobilidade urbana (relações, desemprego, circulação, dispersão, pactos e mecanismos de fugas), o verso parece mais pensado do que escrito, numa aceleração que sugere um traço estilístico saliente, ou seja, um interesse eventual maior em narrar (ou ouvir) do que falar, sintomático no belo poema "Vestido à jovem rico dos torneios": "O jogo fora interrompido por causa/ da chuva, molhados, pregados à cadeira,/ sem nenhuma gente nas filas, hesita$\mathrm{vam} /$ na aflição do primeiro passo. Mas,/ como eram ambos do mesmo gênero,/ali ficaram a ensopar os sapatos/ com as pernas a tremer, o coração/ já normal, a trovoada a passar". Se a narratividade não surpreende tanto como traço da poesia contemporânea, uma vez que as grandes narrativas atingiram o estágio da exaustão, a demanda amorosa permanece atuante e produtiva, talvez um pouco hesitante em espaços exteriores atravessados por fenômenos naturais ou contrafeita em situações acanastradas, mas ávida cada vez mais de claridade e mútua celebração. 